\title{
Correction: Cultivation and genomics of the first freshwater SAR11 (LD12) isolate
}

\author{
Michael W. Henson $(\mathbb{D} \cdot$ V. Celeste Lanclos $\mathbb{1} \cdot$ Brant C. Faircloth · J. Cameron Thrash
}

Published online: 13 December 2019

(c) The Author(s) 2019. This article is published with open access

\section{Correction to: The ISME Journal}

https://doi.org/10.1038/s41396-018-0092-2

Since publication of the original article the authors noticed, regrettably, that the production of the article introduced errors into the nomenclature format for the organism, which were identified by the authors during proofing, but nevertheless remained uncorrected prior to publication of the article.

In the Abstract section "For strain LSUCC0530, we propose the provisional nomenclature Candidatus fonsibacter ubiquis" should read "For strain LSUCC0530, we propose the provisional nomenclature Candidatus Fonsibacter ubiquis". In the Discussion section For the first cultured representative of the LD12 clade, we propose the provisional taxonomic assignment for strain LSUCC0530 as "Candidatus fonsibacter ubiquis" should read For the first cultured representative of the LD12 clade, we propose the provisional taxonomic assignment for strain LSUCC0530 as "Candidatus Fonsibacter ubiquis".

Furthermore, the authors realised they mistakenly used "dehydrogenase" instead of "lyase" in the abstract: "The genome affirms many previous metabolic predictions from cultivation-independent analyses, like a complete Embden-Meyerhof-Parnas glycolysis pathway, but also provides novel insights, such as the first isocitrate dehydrogenase in LD12" should read "The genome affirms many previous metabolic predictions from cultivationindependent analyses, like a complete Embden-MeyerhofParnas glycolysis pathway, but also provides novel insights, such as the first isocitrate lyase in LD12".

The publisher and authors apologise for any inconvenience caused.

Open Access This article is licensed under a Creative Commons Attribution 4.0 International License, which permits use, sharing, adaptation, distribution and reproduction in any medium or format, as long as you give appropriate credit to the original author(s) and the source, provide a link to the Creative Commons license, and indicate if changes were made. The images or other third party material in this article are included in the article's Creative Commons license, unless indicated otherwise in a credit line to the material. If material is not included in the article's Creative Commons license and your intended use is not permitted by statutory regulation or exceeds the permitted use, you will need to obtain permission directly from the copyright holder. To view a copy of this license, visit http://creativecommons. org/licenses/by/4.0/. 